https://doi.org/10.11646/zootaxa.4446.1.5

http://zoobank.org/urn:lsid:zoobank.org:pub:0629A55B-A2DA-4A2C-8DC0-7F34074FCF7E

\title{
Geographic variation in quantitative skull traits and systematic of southern populations of the leaf-eared mice of the Phyllotis xanthopygus complex (Cricetidae, Phyllotini) in southern South America
}

\author{
PABLO TETA ${ }^{1}$, J. PABLO JAYAT ${ }^{2}$, CECILIA LANZONE ${ }^{3,4}$, AGUSTINA OJEDA $^{4}$, \\ AGUSTINA NOVILLO ${ }^{4} \&$ RICARDO OJEDA ${ }^{4}$ \\ 'División Mastozoología, Museo Argentino de Ciencias Naturales "Bernardino Rivadavia” Avenida Ángel Gallardo 470, C1405DJR \\ Buenos Aires, Argentina. E-mail: antheca@yahoo.com.ar \\ ${ }_{2}^{2}$ Instituto de Ambiente de Montaña y Regiones Áridas, Universidad Nacional de Chilecito, Campus Los Sarmiento, Ruta los Peregri- \\ nos s/n, F5360CKB Chilecito, La Rioja, Argentina. \\ ${ }^{3}$ Laboratorio de Genética Evolutiva, FCEQyN, IBS (CONICET-UNaM), Félix de Azara 1552, CP3300 Posadas, Misiones, Argentina. \\ ${ }^{4}$ Grupo de Investigaciones de la Biodiversidad (GIB). Instituto Argentino de Zonas Áridas (IADIZA). CCT-CONICET Mendoza. Ave- \\ nida Ruiz Leal s/n Parque General San Martín CC 507, CP 5500, Mendoza, Argentina.
}

\begin{abstract}
The leaf-eared mice of the genus Phyllotis (Cricetidae, Phyllotini) encompasses at least 20 species of medium-sized Neotropical rodents mostly distributed throughout the Andean region. Its limits and contents were reviewed by several authors, based both on morphological and molecular data. However, no integrative approaches were conducted based on large samples of individuals with a wide geographical coverage. The purposes of this paper are: (i) to evaluate species limits; and (ii) to test the congruence between molecular and quantitative morphological evidences within the Phyllotis xanthopygus complex in southern South America. Our results questioned the specific status of $P$. bonariensis, a geographically isolated form that was either considered as a valid species or as a synonym of $P$. xanthopygus. Quantitative morphological (size and shape of the skull) and molecular data linked P. bonariensis with populations from central Argentina traditionally referred as P. xanthopygus vaccarum. Individuals belonging to populations from southern Argentina and Chile (P. x. xanthopygus) were remarkably homogeneous in their skull morphology, showing a subtle to non-existent differentiation from those of north-central and west-central Argentina referred to $P$. $x$. vaccarum. We found some incongruence between groups inferred from morphological (this work) and mitochondrial DNA results of previous studies. This is the case of the north-central and west-central populations, where morphological traits do not show the strong differentiation detected by molecular characters. Our results highlight the need for integrative taxonomic studies, not only to delimitate taxonomic units but also for a better and more comprehensive understanding of population variability and differentiation.
\end{abstract}

Key words: Phyllotis bonariensis, Phyllotis xanthopygus, Sigmodontinae, taxonomy, quantitative morphology

\section{Introduction}

The genus Phyllotis Waterhouse, 1837 encompasses at least 20 species of medium-sized sigmodontine rodents widely distributed from the highlands of Ecuador, throughout the Andes and adjacent arid and semiarid environments, to the southern tip of continental South America (Pacheco et al., 2014; Rengifo \& Pacheco, 2015; Steppan \& Ramírez, 2015; Jayat et al., 2016). This genus is one of the most studied taxa of South American mammals (e.g., Pearson, 1958; Hershkovitz, 1962; Steppan, 1998); its limits and contents were reviewed by several authors, including both morphological (e.g., Pearson, 1958; Hershkovitz, 1962) and molecular (e.g., Steppan et al., 2007) based approaches.

Within this genus, the most widely distributed species is P. xanthopygus (Waterhouse, 1837), a taxon previously considered as synonym of $P$. darwini (Waterhouse, 1837) (e.g., Pearson, 1958; Hershkovitz, 1962). 
However, both taxa present barriers of reproductive isolation, which confirms their specific status (Walker et al., 1984). As currently understood, P. xanthopygus includes populations in the high Andes and adjacent shrubland habitats along the eastern and western Andean slopes, from central Peru to the provinces of Magallanes in Chile and Santa Cruz in Argentina, and ranging from the sea level to almost 5,600 m a.s.l. (Steppan \& Ramírez, 2015). Phylogenetic analysis of DNA sequences indicated that $P$. xanthopygus is paraphyletic with respect to $P$. bonariensis Crespo, 1964 (Steppan et al., 2007), P. caprinus Pearson, 1958 (Jayat et al., 2016), and P. limatus Thomas, 1912 (Kuch et al., 2002; Steppan et al., 2007), including one to possibly three additional species (Steppan et al. 2007). In a more recent contribution, Riverón (2011) also found deep molecular divergences and a strong geographic structure in the mitochondrial lineages of $P$. xanthopygus.

Currently, P. xanthopygus is composed by at least six subspecies, from north to south: posticalis Thomas, 1912, chilensis Mann, 1945, rupestris Osgood, 1943, ricardulus Thomas, 1919, vaccarum Thomas, 1912, xanthopygus. These taxa were diagnosed by their general body size, external coloration patterns, and minor differences in skull features (Pearson, 1958). The Buenos Aires leaf-eared mouse, Phyllotis bonariensis, a species with a geographically restricted area of distribution and largely isolated from other populations of the same genus, was recovered in some molecular analysis as sister to samples from central Argentina referred as $P$. x. vaccarum (e.g., Steppan et al., 2007). P. bonariensis is endemic to the Ventania hill system, a small hilly belt of $\sim 190 \mathrm{~km}$ in length located in southwestern Buenos Aires Province, central-eastern Argentina, and was either considered as a valid species (e.g., Reig, 1978; Steppan \& Ramírez, 2015), or as a synonym of P. xanthopygus (e.g., Díaz et al., 2006). Crespo (1964) and Steppan and Ramírez (2015) highlighted some striking morphological features of this taxon, including its overall large size and its particularly widened nasals.

The aims of this study are: i) to evaluate species limits; and ii) to test the congruence between molecular and quantitative morphological evidences within southern populations of the Phyllotis xanthopygus complex in southern South America. Special attention is placed regarding the status of $P$. bonariensis, because of its condition of peripheral isolated population.

\section{Materials and methods}

Sampling. A total of 340 individuals of Phyllotis bonariensis, P. xanthopygus vaccarum and P. x. xanthopygus from 78 localities from central and southern Argentina and southern Chile were analyzed (Fig. 1a). These animals are housed in the following museums and collections of Argentina and Chile: CMI, Colección de Mamíferos del Instituto Argentino de Investigaciones de Zonas Áridas, Mendoza, Argentina; CNP, Colección de Mamíferos del Centro Nacional Patagónico, Chubut, Argentina; MACN, Colección Nacional de Mastozoología, Museo Argentino de Ciencias Naturales "Bernardino Rivadavia," Ciudad Autónoma de Buenos Aires, Argentina; UACh, Colección de Mamíferos de la Universidad Austral de Chile, Valdivia, Chile (see Supplementary File 1 for details). Studied specimens included the holotype and paratypes of $P$. bonariensis and several specimens coming from the surroundings of the type locality of vaccarum.

Morphometric data. Seventeen craniodental measurements were taken with digital calipers to the nearest 0.01 mm, following the definitions of Steppan (1997) and Rengifo \& Pacheco (2015): total length of the skull (TLS); condylo-incisive length (CIL); rostrum width (RW); interorbital constriction (IOC); greatest zygomatic breadth (ZB); breadth of braincase (BB); nasal length (NL); nasal width (NW); frontal length (FL); parietal length (PL); upper diastema length (DL); incisive foramina length (IFL); incisive foramina breadth (IFB); upper toothrow length (TRL); palatal bridge (PB); breadth of palate at the level of the first upper molar (BPM1); zygomatic plate breadth (ZPB). Only adult specimens, defined as those of the ages 3-5 (sensu Steppan, 1997), were measured and included in multivariate analyses (see below).

Geographic variation. To conduct subsequent quantitative morphological analyses, studied specimens were grouped following two different procedures (Fig. 1b; Table 1):

First, we grouped the individuals of nearby localities to obtain larger samples for the statistical analyses (see Musser, 1968; Vanzolini, 1970). We follow a criterion of geographic proximity and absence of major geographical barriers among localities, as well as the lack of obvious discrepancies in size and shape among groups (see Brennand et al., 2013; Libardi \& Percequillo, 2016 for a similar procedure). Under this method, the following groups were established (Fig. 1b): busw $=$ southwestern Buenos Aires $(n=21)$; chce $=$ central Chubut $(n=18)$; 
chnc $=$ north-central Chubut $(n=27)$; chsc $=$ south-central Chubut $(n=1)$; chse $=$ south-eastern Chubut $(n=20)$; chsw = south-western Chubut and adjacent Chile $(\mathrm{n}=10)$; chwe $=$ western Chubut $(\mathrm{n}=21)$; coce $=$ central Córdoba $(\mathrm{n}=8)$; menw $=$ north-western Mendoza $(\mathrm{n}=13)$; mese $=$ south-eastern $\operatorname{Mendoza}(\mathrm{n}=1) ; \boldsymbol{m e s o}=$ southern Mendoza $(n=1) ; \mathbf{m e s w}=$ south-western Mendoza $(n=8)$; mewe $=$ western Mendoza $(n=14)$; $\mathbf{n q n e}=$ north-eastern Neuquén $(\mathrm{n}=20)$; nqnw = north-western Neuquén $(\mathrm{n}=24)$; nqso = southern Neuquén $(\mathrm{n}=7)$; rnce $=$ central Río Negro $(n=1)$; rnsc $=$ south-central Río Negro $(n=34)$; scne $=$ north-eastern Santa Cruz $(n=23)$; scnw $=$ north-western Santa Cruz $(n=23) ; \mathbf{s c w c}=$ west-central Santa Cruz $(n=39) ;$ slno = northern San Luis $(n=$ 6). Samples from chsc, mese, meso and rnce were composed by only one specimen each and were therefore excluded from this analysis. Specimens from busw correspond to P. bonariensis, while the remaining samples could be referred to the current concept of $P$. xanthopygus. Within the latter, specimens from coce, menw, mese, meso, mesw, nqne, nqnw and slno are usually included under $P$. $x$. vaccarum, while those of chnc, chwe, chce, chse, chsw, chsc, nqso, rnce, rnsc, scne, scwc, and scnw are traditionally assigned to P. x. xanthopygus (e. g., Pearson 1958; Steppan 1998).

TABLE 1. Correspondence between the geographical groups as were defined by this study and the mitochondrial lineages proposed by Riverón (2011). In boldface are remarked those geographical groups in which two mitochondrial lineages were found in sympatry.

\begin{tabular}{|c|c|c|}
\hline & Geographic & Mitochondrial \\
\hline South-western Buenos Aires & busw & bona \\
\hline North-central Chubut & chnc & south \\
\hline Central Chubut & chce & south \\
\hline North-central Chubut & chnc & south \\
\hline South-central Chubut & chsc & south \\
\hline South-eastern Chubut & chse & south \\
\hline Western Chubut & chwe & south \\
\hline Central Córdoba & coce & central \\
\hline North-western Mendoza & menw & north \\
\hline South-eastern Mendoza & mese & north \\
\hline Southern Mendoza & meso & north/west \\
\hline South-western Mendoza & mesw & north/west \\
\hline Western Mendoza & mewe & north \\
\hline North-eastern Neuquén & nqne & north \\
\hline North-western Neuquén & nqnw & north \\
\hline Southern Neuquén & nqso & north \\
\hline Central Río Negro & rnce & south \\
\hline South-central Río Negro & rnsc & south \\
\hline North-eastern Santa Cruz & scne & south \\
\hline West-central Santa Cruz & scwc & south \\
\hline North-western Santa Cruz & scnw & south \\
\hline Northern San Luis. & slno & central \\
\hline
\end{tabular}

Second, the same sets of individuals were assigned to one of the five mitochondrial lineages documented by Riverón (2011) within southern populations of Phyllotis (see also Steppan et al., 2007). We chose this study as reference because its broad geographical coverage and large number of sequenced specimens, especially from southern populations of the $P$. xanthopygus complex. Groups defined under this procedure were (Fig. 1b): bona = P. bonariensis $(\mathrm{n}=21)$; central $=$ central Argentina $(=$ clade $C 1$ of Riverón, 2011) $(\mathrm{n}=14)$; north $=$ north-central Argentina $(=$ clade NC) $(n=55)$; west $=$ west-central Argentina $(=$ clade $C 2)(n=31)$; south $=$ southern Argentina and Chile (= clade $\mathrm{S})(\mathrm{n}=216)$. Assignation of each individual specimen to the different groups follows a criterion 
of geographic proximity, except for those areas of sympatry or parapatry between lineages (e.g., southern Mendoza and Neuquén) where only sequenced specimens were included in the analysis.

Quantitative morphological patterns of geographic and phylogenetic variations were assessed through a Principal Components Analysis (PCA) using geographical groups and mitochondrial lineages, respectively, as the grouping variables. The PCs were extracted from the variance-covariance matrix and computed by using the variables after transformations to $\log 10$. We analyze both the size and shape of the skull; to construct the shape variable PCA, Mosimann shape variables were calculated through geometric mean transformation of data prior to statistical analyses (Mosimann \& James, 1979). The geometric mean (GM) is a size variable derived from the $\mathrm{n}^{\text {th }}$ root of the product of $n$ measurements, and the ratio of any particular measurement to the overall geometric mean is a Mosimann shape variable (see Meachen-Samuels \& Van Valkenburgh, 2009). This was followed by a discriminant function analysis (DA) to reveal those variables that contribute most to the distinctiveness among groups.

To visualize geographic patterns of variation among localities in the uni- and multivariate space, we constructed Dice-Leraas diagrams showing the mean and 95\% confidence intervals using the geometric mean (see above) and the first two size dependent PCs. To conduct these analyses, only localities with $>10$ specimens were included. A similar procedure was employed by Libardi \& Percequillo (2016) to detect clinal patterns of variation in Euryoryzomys russatus (Sigmodontinae, Oryzomyini). All analyses were made with the software InfoStat (Di Rienzo et al., 2008).

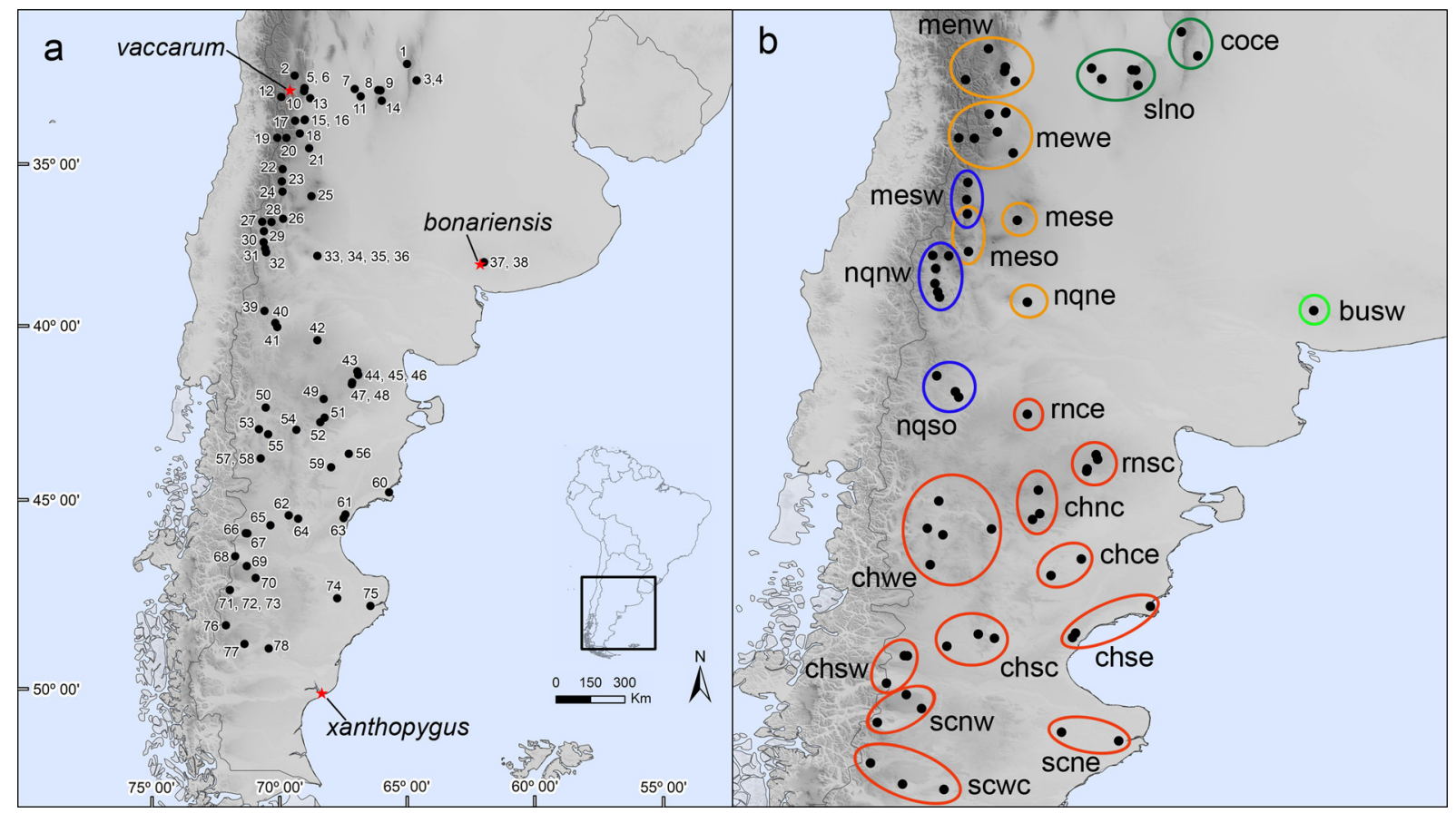

FIGURE 1. a) Map of southern South America indicating the placement of the collection localities of the specimens of Phyllotis studied in this work (see Appendix 1 for a detail); type localities of nominal forms discussed in the text were indicated by red stars. b) Geographical groups recognized in this study; different colors correspond to the mitochondrial lineages documented by Riverón (2011) as follow: light green = bona (P. bonariensis); dark green = central Argentina; orange = northcentral Argentina; blue = west-central Argentina; red = southern Argentina and Chile. For the acronyms, see Materials and Methods section. Specimens from busw correspond to P. bonariensis, while the remaining samples could be referred to the current concept of $P$. xanthopygus; individuals from coce, menw, mese, meso, mesw, nqne, nqnw and slno are usually included under $P$. $x$. vaccarum, while those of chnc, chwe, chce, chse, chsw, chsc, nqso, rnce, rnsc, scne, scwc, and scnw are traditionally assigned to $P$. x. xanthopygus.

\section{Results}

Morphometric variation of the geographical grouped samples. The first three principal components (PCs) of the PCA of base 10 log-transformed measurements accounted for $71.76 \%$ of the total variance (Fig. 2a; Table 2). Plot 
of individual scores showed a marked superimposition of individuals from different groups along the first and second PCs, with some tendency to aggregate in two main clusters: the first encompassing busw, coce, slno, menw, meso, mesw, mewe, nqne, nqnw, and nqso, and the second including chce, chnc, chsc, chse, chsw, chew, rnsc, scne, scnw, and scwc (Fig. 2a; Table 2). On PC1, the highest positive loadings respectively correspond to ZPB, RW, DL and IFW (Table 2). On PC2, the largest positive loadings were CIL, NL, ZPB, and PL and the lowest negative were FL and IFW (Table 2).

TABLE 2. Results of size dependent and shape variable principal components analyses performed on adult individuals (ages 3-5) of Phyllotis $(\mathrm{N}=336)$. See Materials and Methods for explanation of the abbreviations.

\begin{tabular}{|c|c|c|c|c|c|c|}
\hline & \multicolumn{3}{|c|}{ Size dependent PCA } & \multicolumn{3}{|c|}{ Shape variable PCA } \\
\hline & PC 1 & PC 2 & PC 3 & PC 1 & PC 2 & PC 3 \\
\hline TLS & 0.206 & 0.1161 & 0.0442 & 0.0162 & -0.0794 & 0.0504 \\
\hline CIL & 0.2485 & 0.1416 & 0.039 & -0.0378 & -0.1461 & 0.0649 \\
\hline NL & 0.2652 & 0.2365 & -0.1298 & -0.0507 & -0.3164 & -0.0406 \\
\hline NW & 0.2893 & -0.0772 & -0.1147 & -0.1697 & 0.0421 & -0.1501 \\
\hline RW & 0.3231 & 0.029 & -0.1522 & -0.1724 & -0.0771 & -0.1761 \\
\hline IOC & -0.0068 & -0.0508 & -0.0486 & 0.3095 & 0.3621 & -0.2139 \\
\hline FL & 0.2458 & -0.4852 & 0.7253 & -0.2057 & 0.6263 & 0.5767 \\
\hline PL & -0.0223 & 0.5598 & 0.021 & 0.5715 & -0.1428 & -0.1564 \\
\hline ZB & 0.206 & 0.1134 & 0.0287 & 0.0212 & -0.0679 & 0.0306 \\
\hline BB & 0.0391 & 0.1371 & 0.0723 & 0.2818 & 0.0824 & 0.0149 \\
\hline$\underline{Z} P B$ & 0.3226 & 0.3222 & 0.2497 & -0.1103 & -0.4511 & 0.4324 \\
\hline PB & 0.2321 & 0.0022 & 0.1365 & -0.0303 & 0.0938 & 0.0568 \\
\hline IFL & 0.257 & 0.0766 & 0.0542 & -0.0752 & -0.0921 & 0.0676 \\
\hline IFW & 0.4198 & -0.4331 & -0.5658 & -0.5264 & 0.1503 & -0.5701 \\
\hline DL & 0.332 & 0.1102 & 0.0483 & -0.1782 & -0.2044 & 0.1002 \\
\hline TRL & 0.1231 & 0.063 & 0.0275 & 0.1502 & 0.1157 & -0.0583 \\
\hline BPM1 & 0.0832 & 0.086 & 0.0367 & 0.2063 & 0.1046 & -0.0288 \\
\hline Eigenvalue & 0.0076 & 0.0016 & 0.0009 & 0.0026 & 0.0013 & 0.0009 \\
\hline$\%$ variance & 53.53 & 11.58 & 6.65 & 31.81 & 16.08 & 11.08 \\
\hline
\end{tabular}

For the size dependent DFA, the first three axes summarized $70.2 \%$ of the total variation (Fig. 2b; Table 3). Multivariate spaces for the different geographical groups strongly overlapped along the first and second axes, except for those that correspond to busw, coce and slno. Dimensions related to RW, FL, NW and IFW were relevant for discrimination on the first axis and PL, FL, IFW, and ZPB on the second (Table 3).

The first three principal components of the PCA of base 10 log-transformed shape variables (Mosimann variables) accounted for $58.97 \%$ of the total variance (Fig. 3a; Table 2). Grouping tendencies were similar to those documented for the PCA of base 10 log-transformed measurements, although with a more marked superimposition of individuals in the multivariate space (Fig. 3a; Table 2). On PC1, the highest positive loadings correspond to BPM1, BB, IOC, and PL, while IFW, FL, DL, and RW reached the lowest negative loadings (Table 2). On PC2, the largest positive loadings were for FL, IOC, IFW, and TRL, while the lowest negative loadings correspond to TLS, $\mathrm{DL}, \mathrm{BB}$, and FL.

The first three axes of the DFA based on shape variables summarized $92.15 \%$ of the total variation (Fig. $3 b$; Table 3). Multivariate spaces for the different geographical groups strongly overlapped along the first and second axes, except for busw. Dimensions related to RW, FL, NW, and IFW were relevant for discrimination on the first axis and FL, IFL, IOC, and DL on the second (Table 3).

Clinal pattern of variation for the geometric mean was found in a NE-SW transect, using samples from southwestern Buenos Aires province and southern Argentina and Chile. Overall, the geometric mean decreased 
from southwestern Buenos Aires (= busw) towards to southwestern Santa Cruz (= scwc) (Fig. 4a). This trend was also detected by the Dice-Leraas diagrams for the PC1 (Fig. 4b).

Morphometric variation of the mitochondrial lineages grouped samples. Both the PCA of base $10 \log$ transformed measurements and the PCA of base $10 \log$-transformed shape variables (Mosimann variables) showed the same pattern depicted by those PCA constructed using geographical groups as grouping variable (see the description above; Fig. 2c, 3c; Table 2).

The first three axes of the size dependent DFA summarized $70.20 \%$ of the total variation (Fig. 2d). Multivariate spaces for the different mitochondrial lineages strongly overlapped along the first and second axes, except for those that correspond to bona and central. Dimensions related to IFW, PL, NW, and BB were relevant for discrimination on the first axis and PL, Fl, ZPB, and IOC on the second one (Table 3).

The first three axes of the DFA based on shape variables summarized $93.93 \%$ of the total variation (Fig. 3d). Plot of individual scores showed a marked superimposition of specimens from different mitochondrial lineages along the first and second axes, except for bona and central. Dimensions related to DL, IFW, PL, and NW were relevant for discrimination on the first axis and FL, IOC, PL, and IFL on the second axis (Table 3).
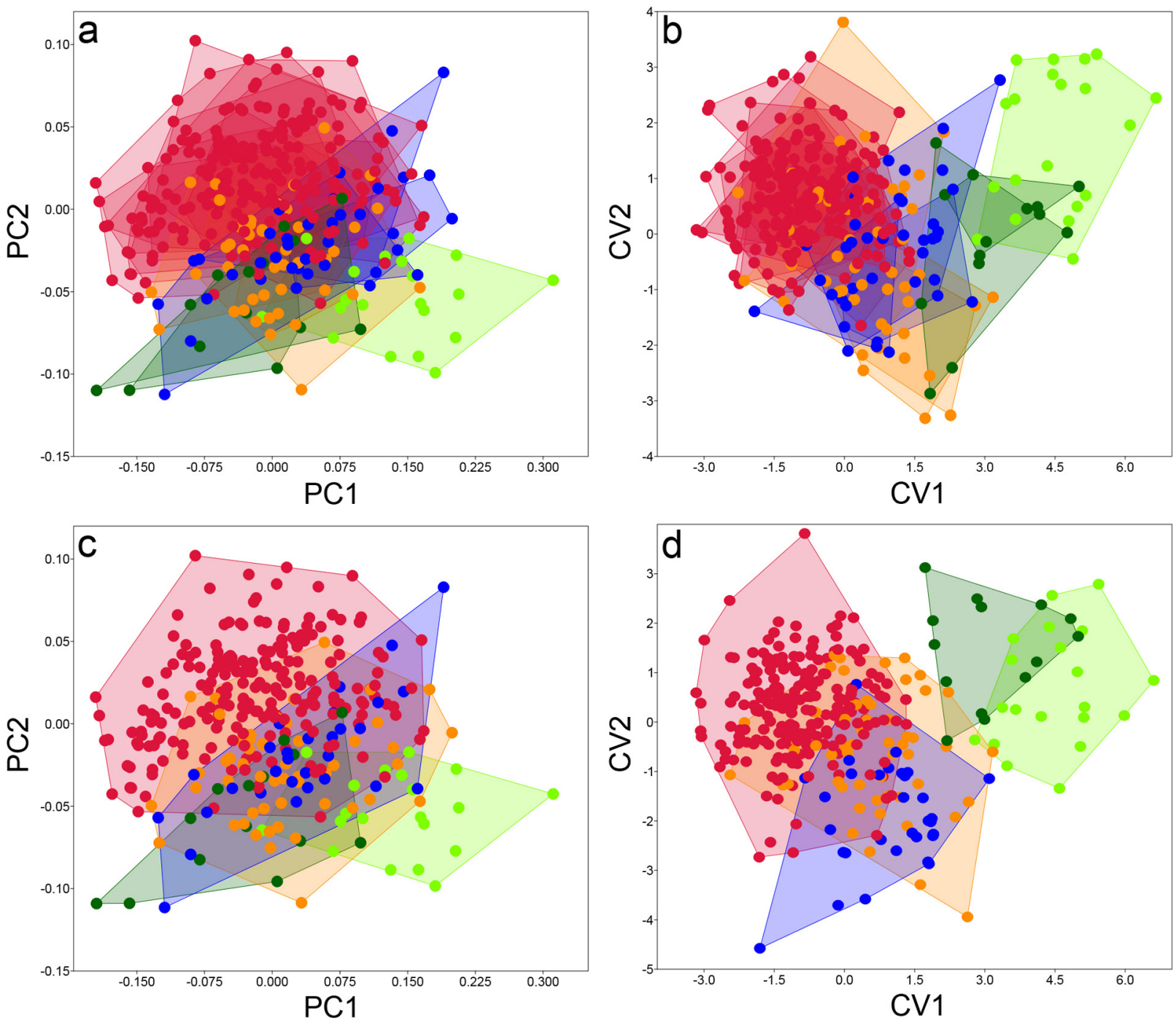

FIGURE 2. Specimen scores of adult individuals (ages 3-5) of Phyllotis $(\mathrm{N}=336)$ for: a) Size dependent principal components 1 and 2 (light green = busw; dark green = coce and slno; orange = menw, mewe and nqne; blue = mesw, nqnw, nqso; red = chce, chnc, chsc, chse, chsw, chew, rnsc, scne, scnw, scwc); b) Size dependent canonical variates 1 and 2 extracted from 18-group discriminant function analysis based on samples grouped by its geographical origin (colors as in A); c) Size dependent principal components 1 and 2 (light green = bona; dark green = cent; yellow = nort; blue = west; red = sout); and d) Size dependent canonical variates 1 and 2 extracted from 5-group discriminant function analysis based on samples grouped by its membership to mitochondrial lineages (colors as in C). For the acronyms, see Materials and Methods section. 
TABLE 3. Results of size dependent and shape variable discriminant function analysis performed on adult individuals (ages 3-5) of Phyllotis ( $\mathrm{N}=336)$. See Materials and Methods for explanation of the abbreviations.

\begin{tabular}{|c|c|c|c|c|c|c|c|c|c|c|c|c|}
\hline & \multicolumn{6}{|c|}{ Size dependent DFA } & \multicolumn{6}{|c|}{ Shape variable DFA } \\
\hline & \multicolumn{3}{|c|}{ Geographical groups } & \multicolumn{3}{|c|}{ Mitochondrial lineages } & \multicolumn{3}{|c|}{ Geographical groups } & \multicolumn{3}{|c|}{ Mitochondrial lineages } \\
\hline & CV1 & $\mathrm{CV} 2$ & CV3 & CV1 & CV2 & $\mathrm{CV} 3$ & CV1 & $\mathrm{CV} 2$ & CV3 & CV1 & CV2 & $\mathrm{CV} 3$ \\
\hline TLS & 0.0015 & & -0.0047 & & & -0.0015 & & & -0.0057 & & -0.0003 & -0.0020 \\
\hline CIL & 0.0018 & -0.0022 & -0.0057 & -0.0019 & -0.0031 & -0.0014 & 0.0017 & -0.0031 & -0.0067 & 0.0019 & -0.0011 & -0.0016 \\
\hline NL & 0.0018 & -0.0013 & -0.0047 & -0.0018 & -0.0023 & -0.0025 & 0.0017 & -0.0008 & -0.0069 & 0.0019 & 0.0010 & -0.0037 \\
\hline NW & 0.0106 & 0.0032 & -0.0013 & 0.0070 & 0.0036 & -0.0031 & 0.0107 & 0.0032 & -0.0103 & -0.0071 & 0.0047 & 0.0050 \\
\hline RW & 0.0085 & 0.0057 & -0.0009 & 0.0049 & 0.0062 & -0.0024 & 0.0084 & 0.0047 & -0.0125 & -0.0048 & 0.0058 & 0.0064 \\
\hline IOC & 0.0026 & 0.0042 & 0.0053 & -0.0010 & 0.0081 & -0.0075 & 0.0029 & 0.0078 & 0.0004 & 0.0008 & 0.0110 & -0.0042 \\
\hline FL & 0.0102 & -0.0081 & -0.0130 & 0.0065 & -0.0105 & 0.0043 & 0.0104 & -0.0156 & -0.0013 & -0.0067 & -0.0126 & -0.0090 \\
\hline PL & -0.0082 & 0.0121 & -0.0027 & -0.0118 & 0.0143 & 0.0063 & -0.0085 & 0.0042 & -0.0066 & 0.0121 & 0.0067 & 0.0075 \\
\hline ZB & 0.0016 & -0.0007 & -0.0038 & -0.0021 & -0.0011 & -0.0027 & 0.0016 & -0.0010 & -0.0064 & 0.0020 & 0.0011 & -0.0020 \\
\hline BB & -0.0030 & 0.0041 & -0.0017 & -0.0066 & 0.0049 & -0.0017 & -0.0029 & 0.0019 & -0.0069 & 0.0065 & 0.0039 & -0.5443 \\
\hline ZPB & 0.0007 & -0.0050 & -0.0104 & -0.0029 & -0.0088 & -0.2400 & 0.0009 & -0.0060 & -0.0087 & 0.0027 & -0.0042 & 0.0001 \\
\hline PB & 0.0077 & 0.0029 & -0.0116 & 0.0041 & -0.0007 & 0.0064 & 0.0075 & -0.0058 & -0.0110 & -0.0039 & -0.0044 & 0.0028 \\
\hline IFL & 0.0027 & -0.0022 & -0.0106 & -0.0009 & -0.0041 & 0.0046 & 0.0026 & -0.0086 & -0.0087 & 0.0010 & -0.0067 & 0.0022 \\
\hline IFW & & -0.0031 & -0.0052 & & -0.0051 & -0.0039 & & -0.0025 & -0.0057 & -0.0134 & -0.0005 & -0.0051 \\
\hline DL & 0.0038 & -0.0041 & -0.0091 & 0.0002 & -0.0060 & 0.0013 & 0.0037 & -0.0063 & -0.0086 & -0.0901 & -0.0044 & 0.0008 \\
\hline TRL & 0.0019 & 0.0049 & -0.0090 & -0.0017 & 0.0026 & 0.0053 & 0.0018 & -0.0040 & -0.0105 & 0.0018 & -0.0025 & 0.0037 \\
\hline BPM1 & 0.0003 & 0.0038 & -0.0028 & -0.0033 & 0.0036 & -0.0015 & 0.0004 & 0.0007 & -0.0070 & 0.0032 & 0.0027 & -0.0009 \\
\hline Eigenvalue & 2.4708 & 0.7547 & 0.6150 & 2.4550 & 0.6756 & 0.5876 & 2.3089 & 0.5420 & 0.4332 & 2.3024 & 0.5356 & 0.3458 \\
\hline$\%$ variance & 45.16 & 13.8 & 11.24 & 48.08 & 13.23 & 11.52 & 64.78 & 15.21 & 12.16 & 67.93 & 15.8 & 10.2 \\
\hline
\end{tabular}

\section{Discussion}

Geographically grouped samples and groups based on mitochondrial lineages depict a similar pattern of quantitative morphological variation (hereafter, we refer only to mitochondrial lineages to avoid confusions). Despite some tendency to separation between samples from southwestern Buenos Aires (= bona) and from Córdoba and San Luis (= central) in relation to all other populations of the P. xanthopygus complex, the plot of individual scores showed a marked superimposition of individuals from different groups. The overlap among samples was higher when the effect of size was removed, suggesting that differences among bona + central and $P$. xanthopygus s.l. are mostly in size. A main conclusion of these results is that the specific status of those populations from southwestern Buenos Aires province, usually referred as P. bonariensis, is questionable. Plausibly, size differences among populations of $P$. xanthopygus complex could be explained by a clinal pattern of variation from north-east to south-west. This kind of pattern is frequently expressed in continentally distributed species as the result of the interaction of the selective forces and gene flow (Mayr, 1954). Among Neotropical sigmodontine rodents, this topic was poorly addressed, with only few examples in which such kind of patterns were described. For example, Libardi \& Percequillo (2016) found a N-S clinal variation of some cranial measurements in the Atlantic forest dweller Euryoryzomys russatus. Similarly, Pearson \& Smith (1999) and Teta \& Pardiñas (2014) reported changes in the overall size of the body of Abrothrix olivacea and the skull of $A$. hirta across a same large environmental gradient in southern Argentina and Chile. Briefly, these authors found that large animals occur at areas under high primary productivity, while the smaller ones correspond to places with low primary productivity. Both Pearson \& Smith (1999) and Teta \& Pardiñas (2014) suggested that morphological differentiation in these two taxa was probably driven by differential selection across a sharp ecological gradient, in spite of gene flow. 

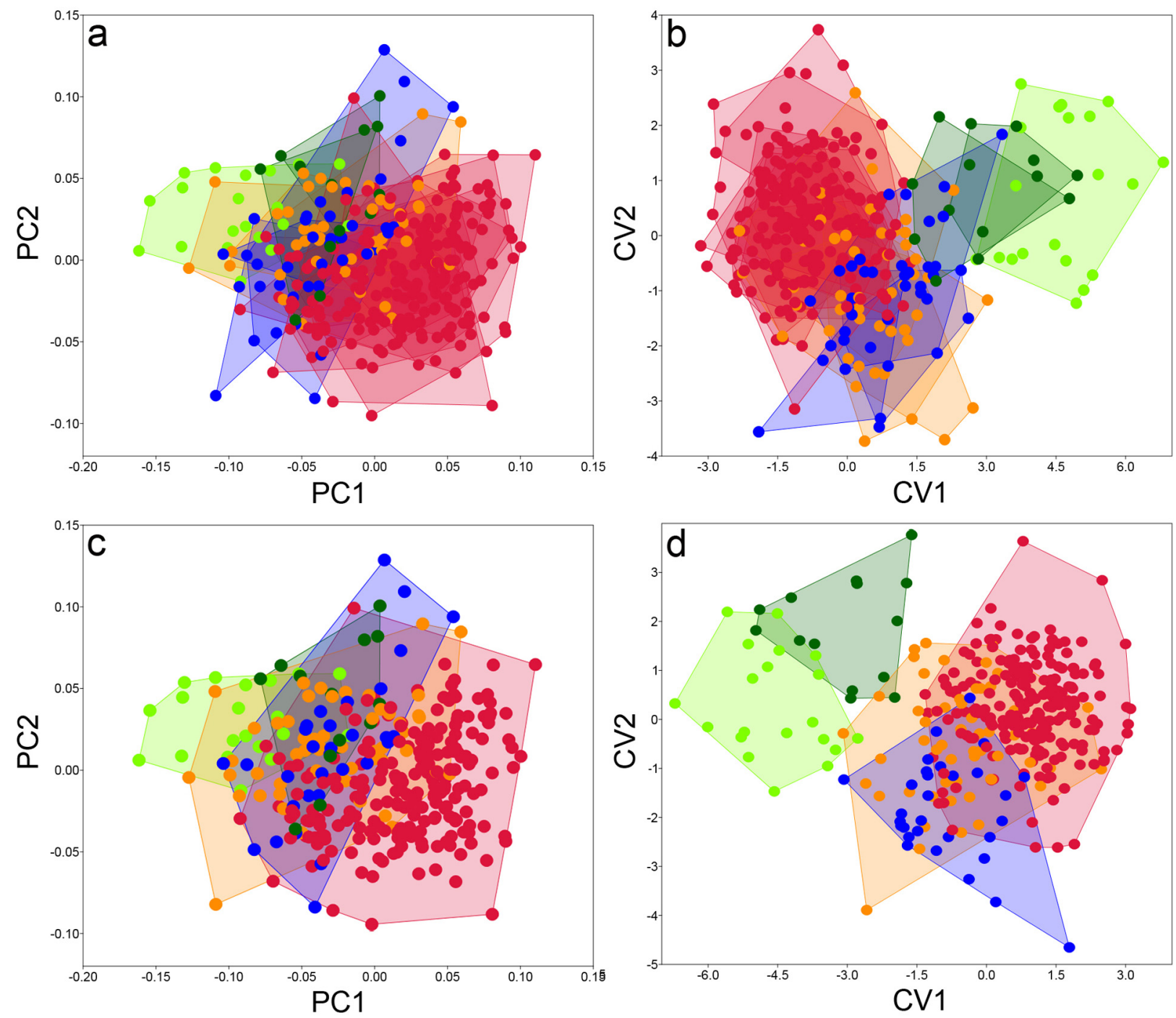

FIGURE 3. Specimen scores of adult individuals (ages 3-5) of Phyllotis $(\mathrm{N}=336)$ for: a) Shape variable principal components 1 and 2 (light green $=$ busw; dark green $=$ coce and slno; orange $=$ menw, mewe and nqne; blue $=$ mesw, nqnw, nqso; red $=$ chce, chnc, chse, chsw, chew, rnsc, scne, scnw, scwc); b) Shape variable canonical variates 1 and 2 extracted from 18-group discriminant function analysis based on samples grouped by its geographical origin (colors as in A); c) Shape variable principal components 1 and 2 (light green $=$ bona; dark green $=$ cent; yellow $=$ nort; blue $=$ west; red $=$ sout ); and ds) Shape variable canonical variates 1 and 2 extracted from 5 -group discriminant function analysis based on samples grouped by its membership to mitochondrial lineages (colors as in C). For the acronyms, see Materials and Methods section.

As is currently understood, P. bonariensis is a geographically isolated form that was either considered as a valid species or as a synonym of P. xanthopygus (e.g., Reig, 1978; Díaz et al., 2006). Crespo (1964) and Steppan \& Ramírez (2015) provided detailed diagnosis of this taxon, highlighting its large-sized body, relatively small ears and hindfeet, well developed vibrissae, large posterolateral palatal pits located anterior to mesopterygoid fossa, markedly wide distal portion of nasals, and orthodont upper incisors. Accordingly, our results suggest that this species is characterized by relatively larger values for the breadth of incisive foramina, width of nasals, and frontal length. However, such kind of morphological differences could be expected in geographically isolated populations, as they are usually exposed to higher rates of morphological evolution via genetic drift by demographic bottlenecks or founder effect (e.g., Mayr, 1954). In agreement with previous molecular based contributions, populations from southwestern Buenos Aires appears to be morphologically linked to those populations in Córdoba and San Luis provinces, in central Argentina (cf. Steppan et al., 2007; Riverón, 2011).

Cranial differences among samples from north-central (= north) and west-central (= west) Argentina and central and southern Patagonia (= south) were subtle to nonexistent. In contrast, Riverón (2011) hypothesized that 
these three same clades (i.e., north, west, and south) could correspond to different species, because these groups were reciprocally monophyletic and their molecular divergences are high, ranging from 9 to $12 \%$ ( $p$ distances; see Riverón, 2011). In this context, the overall similarity in its cranial architecture could be explained by assuming that these populations are expose to relatively similar environmental pressures at their respective distributional ranges (cf. Corrêa-Tavarez et al., 2016). However, based on the limited morphological distinction among different lineages, we hypothesize that these populations (as well as those from southwestern Buenos Aires [= bona] and Córdoba and San Luis [= central]) represents the geographically structured groups of a same biological species (i.e., P. xanthopygus). Accordingly, no major differences were detected in the diploid complement and patterns of G-bands of different populations of $P$. xanthopygus, including samples referable to $P$. $x$. xanthopygus and $P . x$. vaccarum (e.g., Walker et al., 1991; Labaroni et al., 2014). Even more, the phylogenetic analysis of the partial sequence of the nuclear gene $R A G 1$ grouped all samples from regions studied here in the same clade, supporting that all these populations correspond to a unique species. However, this gene has a lower variability than mitochondrial one, and the absence of monophyly in the RAG1 was recorded in mitochondrially divergent Phyllotis species (cyt b results of Steppan et al., 2007). Externally, samples from north-central (= north) and westcentral (= west) Argentina are large-bodied, long-tailed, and pale colored, contrasting with those from southern Argentina and Chile that have proportionately shorter tails, and a relatively dark coloration with a distinctly buffy venter (Pearson, 1958). Additional morphological and genetic studies are needed, including the evaluation of other external and cranial qualitative traits and more variable molecular markers, to evaluate the taxonomic and evolutionary implications of the high $c y t b$ variability and low divergence in quantitative traits of these populations of Phyllotis.

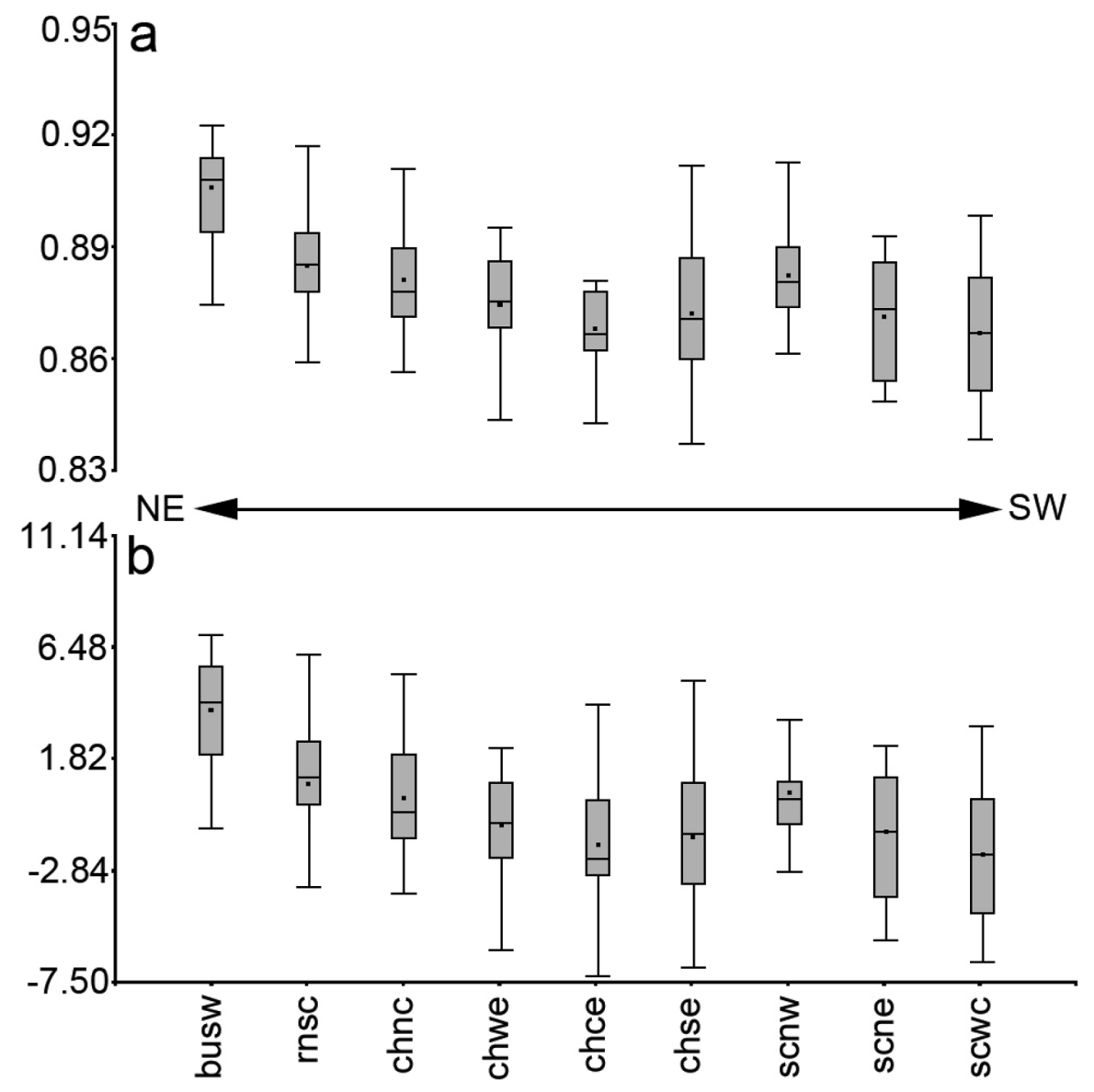

FIGURE 4. Dice-Leraas diagrams elaborated with the geometric mean (a) and individual scores of the first principal component (b) over selected localities of the geographical groups busw, rnsc, chnc, chew, chce, chse, scnw, scne, and scwc in a NE-SW transect. The black spots represent the means; the gray area represent the $95 \%$ confidence intervals and the bars the range. For the acronyms, see Materials and Methods section. 
Quantitative morphological analysis and previous data from molecular markers (Steppan et al., 2007; Riverón, 2011) challenged the current taxonomic scenario within $P$. xanthopygus, showing little correlation of these sets of evidences with traditional subspecies definitions. For example, the supposedly cohesive concept of $P$. x. vaccarum constructed by Pearson (1957) includes at least three divergent mitochondrial lineages, as was documented by Riverón (2011). Two of these lineages (here referred as north and west) are almost indistinguishable at the morphological level, while the third, restricted to the hilly rocky environments of central Argentina (= central), is from a morphological and molecular perspective more closely related to those populations in southwestern Buenos Aires province (= bona). Preliminarily, those populations from central Argentina could be excluded from $P$. $x$. vaccarum, pending its taxonomic status of further studies and the integrative evaluation of other nominal forms (e.g., P. x. ricardulus). Samples from southern Argentina and Chile (= south) were remarkably homogeneous from a morphological perspective, a situation that partially coincides with the hypothesis of a relatively recent expansion of the Patagonian populations from at least one refuge south of $41^{\circ} \mathrm{S}$ (Riverón, 2011) and the traditional view of these samples as part of $P$. x. xanthopygus.

Based both on mitochondrial and nuclear molecular markers, Steppan et al. (2007; see also Jayat et al., 2016) suggested that the widespread species $P$. xanthopygus is characterized by deep divergences, large genetic diversity, and paraphyly with respect to at least three other morphological species (e.g., P. bonariensis, P. caprinus and $P$. limatus). Our quantitative multivariate analysis of skull traits do not contradict this hypothesis, although questioned the validity at the species level of $P$. bonariensis. Almost 60 years after the first comprehensive review of the genus Phyllotis (Pearson, 1958) and successive additional contributions (e.g., Steppan, 1998, Albright, 2004, Riverón, 2011), many questions have been answered and several others were raised around the alpha taxonomy of these rodents. Our results demonstrate the need of detailed morphological studies of geographic variation when exploring systematic issues in largely distributed species. In addition, highlight again the problem of defining taxa only with morphological characters. Additional samples from northern Argentina and Chile, western Bolivia and southern Peru are much needed, in order to advance in a more comprehensive view of the quantitative variation of skull traits within Phyllotis xanthopygus. A complete picture of the alpha taxonomy of this species complex necessarily depends on the evaluation of the taxonomic status of other nominal forms with a northern distribution, which are not included in this study (e.g., posticalis, chilensis, rupestris and ricardulus). Finally, our results highlight the need for integrative taxonomic studies, not only to delimitate taxonomic units, but also for a better and more comprehensive understanding of population variability and differentiation.

\section{Acknowledgements}

We are grateful to the following curators and collection managers for hospitality in the collections and permitting access to specimens: Guillermo D'Elía (UACh), Freddy Mondaca (UACh) and Ulyses F. J. Pardiñas (CNP). Special thanks are extended for E. Lessa and G. D'Elía, which shared with us some unpublished molecular data. This work was also possible thanks to the financial support of PIP CONICET (1122015 $0100258 \mathrm{CO})$ and the institutional support of the Instituto de Ecología Regional (IER-CONICET).

\section{Literature cited}

Albright, J.C. (2004) Phylogeography of the sigmodontine rodent, Phyllotis xanthopygus, and a test of the sensitivity of nested clade analysis to elevation-based alternative distances. Ph. D. Dissertation, The Florida State University, Tallahassee, Florida, 46 pp.

Brennand, P.G.G., Langguth, A.R. \& Percequillo, A.R. (2013) The genus Hylaeamys, Percequillo, and Voss 2006 (Rodentia: Cricetidae: Sigmodontinae) in the Brazilian Atlantic Forest: geographic variation and species definition. Journal of Mammalogy, 94, 1346-1363. https://doi.org/10.1644/12-MAMM-A-312.1

Corrêa-Tavarez, W., Pessôa, L.M. \& Seuánez, H.N. (2016) Stability and acceleration of phenotypic evolution in spiny rats (Trinomys, Echimyidae) across different environments. Zoological Journal of Linnean Society, 178, 149-162. https://doi.org/10.1111/zoj.12406

Crespo, J.A. (1964) Descripción de una nueva subespecie de roedor filotino. Neotrópica, 10, 99-101.

Di Rienzo, J.A., Casanoves, F., Balzarini, M.G., Gonzalez, L., Tablada, M. \& Robledo, C.W. (2008) InfoStat. Versión 2008. Grupo InfoStat, FCA, Universidad Nacional de Córdoba, Córdoba. [software] 
Díaz, M.M., Teta, P., Pardiñas, U.F.J. \& Barquez, R.M. (2006) Tribu Phyllotini. In: Barquez, R.M., Díaz, M.M. \& Ojeda, R.A. (Eds.), Mamíferos de Argentina: Sistemática y distribución. Sociedad Argentina para el Estudio de los Mamíferos, Tucumán, pp. 175-189.

Hershkovitz, P. (1962) Evolution of Neotropical cricetine rodents (Muridae) with special reference to the phyllotine group. Fieldiana Zoology, 46, 1-524.

Jayat, J.P., Ortiz, P.E., González, F.R. \& D’Elía, G. (2016) Taxonomy of the Phyllotis osilae species group in Argentina; the status of the "Rata de los nogales" (Phyllotis nogalaris Thomas, 1921; Rodentia: Cricetidae). Zootaxa, 4083 (3), $397-417$. https://doi.org/10.11646/zootaxa.4083.3.5

Kuch, M., Rohland, N., Betancourt, J.L., Latorre, C., Steppan, S. \& Poinar, H.N. (2002) Molecular analysis of a $11700-$ yearold rodent midden from the Atacama Desert, Chile. Molecular Ecology, 11, 913-924.

Labaroni, C. A., Malleret, M. M., Novillo, A., Ojeda, A., Rodriguez, D., Cuello, P., Ojeda, R. A., Martí, D. \& Lanzone, C. (2014) Karyotypic variation in the Andean rodent Phyllotis xanthopygus (Waterhouse, 1837) (Rodentia, Cricetidae, Sigmodontinae). Comparative Cytogenetics, 8, 369-381. https://doi.org/10.3897/CompCytogen.v8i4.8115

Libardi, G.S. \& Percequillo, A.R. (2016) Variation of craniodental traits in russet rats Euryoryzomys russatus (Wagner, 1848) (Rodentia: Cricetidae: Sigmodontinae) from Eastern Atlantic Forest. Zoologischer Anzeiger, 262, 57-74. https://doi.org/10.1016/j.jcz.2016.03.005

Mayr, E. (1954) Change of genetic environment and evolution. In: Huxley, J.S., Hardy, A.C. \& Ford, E.B. (Eds.), Evolution as a Process. Allen and Unwin, London, UK.

Meachen-Samuels, J. \& Van Valkenburgh, B. (2009) Craniodental indicators of prey size preference in the Felidae. Biological Journal of the Linnean Society, 96, 784-799. https://doi.org/10.1111/j.1095-8312.2008.01169.x

Mosimann, J.E. \& James, F.C. (1979) New statistical methods for allometry with application to Florida red-winged blackbirds. Evolution, 33, 444-459.

Musser, G.G. (1968) A systematic study of the Mexican and Guatemalan graysquirrel: Sciurus aureogaster F. Cuvier (Rodentia: Sciuridae). Miscelaneous Publications of the Museum of Zoology, University of Michigan, 137, 1-112.

Pacheco, V., Rengifo, E.M. \& Vivas, D. (2014) Una nueva especie de ratón orejón del género Phyllotis Waterhouse, 1837 (Rodentia: Cricetidae) del norte del Perú. Therya, 5, 81-508. https://doi.org/10.12933/therya-14-185

Pearson, O.P. (1957) Additions to the mammalian fauna of Peru and notes on some other Peruvian mammals. Breviora, 73, 1-7.

Pearson, O.P. (1958) A taxonomic revision of the rodent genus Phyllotis. University of California, Publications in Zoology, 56, 391-496.

Pearson, O.P. \& Smith, M.F. (1999) Genetic similarity between Akodon olivaceus and Akodon xanthorhinus (Rodentia: Muridae) in Argentina. Journal of Zoology, London, 247, 43-52.

Reig, O.A. (1978) Roedores cricétidos del Plioceno superior de la provincia de Buenos Aires (Argentina). Publicaciones del Museo Municipal de Ciencias Naturales de Mar del Plata Lorenzo Scaglia, 2, 164-90.

Rengifo, E.M. \& Pacheco, V. (2015) Taxonomic revision of the Andean leaf-eared mouse, Phyllotis andium Thomas 1912 (Rodentia: Cricetidae), with the description of a new species. Zootaxa, 4018 (3), 349-380. https://doi.org/10.11646/ zootaxa.4018.3.2.

Riverón, S. (2011) Estructura poblacional e historia demográfica del "pericote patagónico" Phyllotis xanthopygus (Rodentia: Sigmodontinae) en Patagonia Argentina. Ph. D. Dissertation, Universidad de la República, Montevideo, 100 pp.

Steppan, S.J. (1997) Phylogenetic analysis of phenotypic covariance structure. I. Contrasting results from matrix correlation and common Principal Component Analysis. Evolution, 51, 571-586.

Steppan, S.J. (1998) Phylogenetic relationships and species limits within Phyllotis (Rodentia: Sigmodontinae): concordance between mtDNA sequence and morphology. Journal of Mammalogy, 79, 573-593. https://doi.org/10.2307/1382988

Steppan, S.J. \& Ramírez, O. (2015) Genus Phyllotis Waterhouse, 1837. In: Patton, J.L., Pardiñas, U.F.J. \& D’Elía, G. (Eds.), Mammals of South America. Vol. 2. Rodents. The University of Chicago Press, Chicago \& London, pp. 535-555.

Steppan, S.J., Ramirez, O., Banbury, J., Huchon, D., Pacheco, V., Walker, L.I. \& Spotorno, A.E. (2007) A molecular reappraisal of the systematics of the leaf-eared mice Phyllotis and their relatives. In: Kelt, D.A., Lessa, E.P., Salazar-Bravo, J. \& Patton, J.L. (Eds.), The Quintessential Naturalist: Honoring the Life and Legacy of Oliver P. Pearson. University of California, Publications in Zoology, California, pp. 799-826.

Teta, P. \& Pardiñas, U.F.J. (2014) Variación morfológica cualitativa y cuantitativa en Abrothrix longipilis (Waterhouse, 1837) (Cricetidae, Sigmodontinae). Mastozoología Neotropical, 21, 291-309.

Vanzolini, P.E. (1970) Zoologia sistemática: geografia e a origem das espécies. Sér. Teses e Monografias IG/USP, 3, 1-56.

Walker, L.I., Spotorno, A.E. \& Arrau, J. (1984) Cytogenetic and reproductive studies of two nominal subspecies of Phyllotis darwini and their experimental hybrids. Journal of Mammalogy, 65, 220-230. https://doi.org/10.2307/1381161

Walker, L.I., SPotorno, A.E. \& Sans, J. (1991) Genome size variation and its phenotypic consequences in Phyllotis rodents. Hereditas 115: 99-107. https://10.1111/j.1601-5223.1991.tb03542.x. 
APPENDIX 1. List of studied specimens and their collecting localities (arranged by growing latitude). For a reference of the acronyms of museums and biological collections see the section of Materials and methods. AB and PPA correspond to field numbers of specimens housed at CNP. Numbers between brackets correspond to those on Fig. 1.

(1) Río Mina Clavero, Córdoba (-31.735,$\left.-65.008^{\circ}\right)$ : CNP 3361, CNP 3373; (2) Estancia Yalquaraz, Las Heras, Uspallata, Mendoza (-32.117,$\left.-69.400^{\circ}\right)$ : CMI 7352, CMI 7358; (3) $3 \mathrm{~km} \mathrm{~S}$ Cerro Los Linderos, Calamuchita, Córdoba (-32.278 ${ }^{\circ}$, 64.631 ${ }^{\circ}$ ): CNP 3710, CNP 3874; (4) La Tapera, Córdoba (-32.278 $\left.{ }^{\circ},-64.631^{\circ}\right)$ : CNP 3362, CNP 3374, CNP 3375, CNP 3376; (5) Villavicencio, Las Heras, Mendoza (-32.532 , $\left.-69.015^{\circ}\right)$ : CMI 6225, CMI 6226, CMI 6227; (6) 2 km S Villavicencio, RP32, Las Heras, Mendoza (-32.532,$\left.-69.015^{\circ}\right)$ : CMI 3445; (7) Parque Nacional Sierra de Las Quijadas, San Luis (-32.561 ${ }^{\circ}$, 67.053): CMI 3850; (8) San Francisco del Monte de Oro, 2800 m, Quebrada de López, Ayacucho, San Luis (-32.599, 66.132 ${ }^{\circ}$ : CMI 5570; (9) $7 \mathrm{~km}$ E San Francisco del Monte de Oro, río Gómez, Ayacucho, San Luis (-32.607 $\left.{ }^{\circ},-66.0458^{\circ}\right)$ : CMI

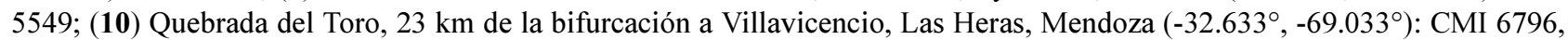
CMI 6797, CMI 6798, CMI 6799, CMI 7061; (11) 12 km NW Los Araditos, 2800 m, La Calera, Belgrano, San Luis (-32.804º, -66.822 $)$ : CMI 5583; (12) Puente del Inca, Las Heras, Mendoza (-32.822 $\left.2^{\circ},-69.923^{\circ}\right)$ : CMI 7317; (13) Cuenca del Maure, Godoy Cruz, Mendoza (-32.861 $\left.{ }^{\circ},-68.791^{\circ}\right)$ : CMI 7300; (14) $1 \mathrm{~km} \mathrm{~N}$ Paso del Rey, a lo largo del arroyo Cañada Honda, 4400 m, Coronel Pringles, San Luis $\left(-32.950^{\circ},-65.999^{\circ}\right)$ : CMI 5561, CMI 5562; (15) Valle de Uco, Gral. Alvarado, Mendoza (33.562 $\left.{ }^{\circ},-69.003^{\circ}\right)$ : CMI 7346; (16) Tunuyan, Mendoza (-33.581 $\left.{ }^{\circ},-69.014^{\circ}\right)$ : CMI 7318; (17) Manzano Histórico, Tunuyan, Mendoza (-33.602 $\left.{ }^{\circ},-69.383^{\circ}\right)$ : CMI 7337; (18) $3 \mathrm{~km}$ O refugio militar Gral. Alvarado, San Carlos, Mendoza (-34.010 ${ }^{\circ}$, 69.198 ${ }^{\circ}$ : CMI 5629, CMI 5630; (19)10 km S de Las Leñas, margen río Salado, $1900 \mathrm{~m}$, Malargue, Mendoza (-34.149, -

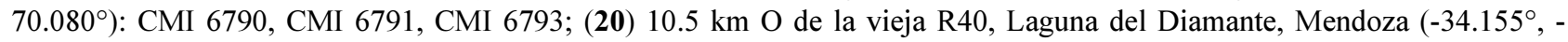
69.720): CMI 2191, CMI 2195, CMI 2197, CMI 2198, CMI 2199, CMI 2202, CMI 2204, CMI 2249; (21) 40.2 km O R150, 25 de Mayo, Mendoza (-34.489,$\left.-68.837^{\circ}\right)$ : CMI 2151; (22) Laguna de la Niña Encantada, Malargue, Mendoza (-35.159 ${ }^{\circ}$, 69.869 ${ }^{\circ}$ : CMI 7344; (23) La Valenciana, Mendoza (-35.548 $\left.{ }^{\circ},-69.899^{\circ}\right)$ : CNP 1893; (24) Bardas Blancas, Mendoza $\left(-35.874^{\circ}\right.$, -69.8794 ${ }^{\circ}$ ): CNP 3360; (25) Base del Cerro Colorado, Mendoza (-36.019,$\left.-68.745^{\circ}\right)$ : CNP 3528; (26) $70 \mathrm{~km} \mathrm{E} \mathrm{Barrancas,}$ Mendoza (-36.729,$\left.-69.855^{\circ}\right)$ : CMI 5301; (27) $3 \mathrm{~km} \mathrm{~N}$ Varvarco, Neuquén $\left(-36.819^{\circ},-70.671^{\circ}\right)$ : AB 52, AB 54, AB 55, AB 56; (28) Área Natural Protegida Domuyo (-36.829,$\left.-70.308^{\circ}\right)$ : CNP 3734, CNP 4279, CNP 4283, CNP 4426, CNP 4452, CNP 4530, CNP 4574, PPA 225, PPA 226, PPA 231, PPA 234; (29) Área Natural Protegida Cañada Molina, Neuquén (-37.117º 70.603 ${ }^{\circ}$ : $\mathrm{AB} 35, \mathrm{AB} 43, \mathrm{AB} 45, \mathrm{AB} 46 ;$ (30) $2.5 \mathrm{~km} \mathrm{~S}$ El Cholar, sobre RP21, Neuquén $\left(-37.458^{\circ},-70.619^{\circ}\right)$ : AB 60, AB 67; (31) 3 km SE El Huecú, Neuquén $\left(-37.650^{\circ},-70.559^{\circ}\right)$ : AB 81, MACN 20980; (32) Ranquilon, Neuquén $\left(-37.767^{\circ},-70.517^{\circ}\right)$ : MACN 21316; (33) Auca Mahuida, Neuquén (-37.882 $\left.{ }^{\circ},-68.514^{\circ}\right)$ : AB 110, CNP 4099, CNP 4101; (34) Auca Mahuida, Rincón del Palo Blanco, Neuquén (-37.882 $\left.{ }^{\circ},-68.514^{\circ}\right)$ : CNP 3661, CNP 3667, CNP 3671, CNP 3679, CNP 3681, CNP 3683, CNP 3692, CNP 3693, CNP 3697, CNP 3795, CNP 4392, CNP 4422, PPA 125, PPA 149; (35) Auca Mahuida, camino a pozo LaMa XI, Neuquén $\left(-37.882^{\circ},-68.514^{\circ}\right)$ : PPA 163; (36) Auca Mahuida, Riscos Altos (-37.882 $\left.{ }^{\circ},-68.514^{\circ}\right)$ : CNP 4428, PPA 142; (37) Parque Provincial Ernesto Torquinst, Sierra de la Ventana, Buenos Aires (-38.072 $\left.{ }^{\circ},-61.994^{\circ}\right)$ : CNP 3350, CNP 3351, CNP 3553, CNP 3807, CNP 3808, CNP 3816, CNP 3817 CNP 4577, CNP 4579, CNP 4580, CNP 4584, CNP 4585, CNP 4586, CNP 811; (38) Abra de la Ventana, Parque Provincial Ernesto Torquinst, Sierra de la Ventana, Buenos Aires (-38.072 ${ }^{\circ}$, 61.994): MACN 14914, MACN 14915, MACN 14917, MACN 14918, MACN 14919, MACN 14920; (39) Las Coloradas, Neuquén $\left(-39.555^{\circ},-70.579^{\circ}\right)$ : MACN 13482, MACN 15527, MACN 15528, MACN 18199; (40) Estancia Santa Teresa, $15 \mathrm{~km}$ RN237, Neuquén (-39.919,$\left.-70.156^{\circ}\right)$ : AB 87, AB 97; (41) Piedra del Aguila, Neuquén $\left(-40.043^{\circ},-70.079^{\circ}\right)$ : CNP 3353; (42) Puesto Pillahuinco, Estancia La Esperanza, Río Negro (-40.432 $\left.{ }^{\circ},-68.514^{\circ}\right)$ : CNP 3672; (43) Puesto Buñuelo, Río Negro (41.351 $\left.{ }^{\circ},-66.951^{\circ}\right)$ : CNP 3419; (44) Cerro Corona, Rio Negro $\left(-41.456^{\circ},-66.914^{\circ}\right)$ : CNP 3349, CNP 3377; (45) Puesto Quiñelaf, Río Negro (-41.456,$\left.-66.914^{\circ}\right)$ : CNP 3346; (46) Meseta de Somuncurá, Río Negro (-41.456 $\left.{ }^{\circ},-66.914^{\circ}\right)$ : CNP 17, CNP 3358, CNP 3359, CNP 3363, CNP 3365, CNP 3366, CNP 3367, CNP 3368, CNP 3369, CNP 3370, CNP 3372, CNP 3422, CNP 3423; (47) Subida de las Nacientes, Meseta de Somuncurá, Río Negro (-41.673ㅇ -67.1542 ${ }^{\circ}$ ): CNP 867, CNP 868, CNP 3309, CNP 3310, CNP 3311, CNP 3312, CNP 3313, CNP 3314, CNP 3314, CNP 3315, CNP 3316, CNP 3347, CNP 3420; (48) Estancia San Nicolás, Río Negro (-41.731 $\left.{ }^{\circ},-67.164^{\circ}\right)$ : CNP 3329, CNP 3330, CNP 3344, CNP 3345; (49) Estancia Talagapa, Chubut $\left(-42.156^{\circ},-68.265^{\circ}\right)$ : CNP 1078, CNP 1105, CNP 1144, CNP 1185, CNP 178, CNP 1903, CNP 3538; (50) Paraje Fofocahuel, Chubut $\left(-42.404^{\circ},-70.532^{\circ}\right)$ : CNP 262; (51) Establecimiento La Maroma, Chubut $\left(-42.694^{\circ},-68.234^{\circ}\right)$ : CNP 3669, CNP 3673, CNP 3676, CNP 3680, CNP 3689, CNP 3694, CNP 3695, CNP 3758, CNP 4098, CNP 4285, CNP 4293, CNP 4298, CNP 4332, CNP 4427, CNP 4430, CNP 4563; (52) Caruhé Niyeu, Chubut $\left(-42.825^{\circ},-68.397^{\circ}\right)$ : CNP 3338 , CNP 3984, CNP 4100, CNP 4418; (53) Cabaña arroyo Pescado, Chubut (-43.025\%; $\left.-70.793^{\circ}\right)$ : CNP 1064, CNP 1325, CNP 1551, CNP 1619, CNP 1661, CNP 903, CNP 980, CNP 989; (54) Estancia Leleque, Chubut (-43.041 $\left.{ }^{\circ},-69.332^{\circ}\right)$ : CNP 1334 , CNP 1651, CNP 1665; (55) Laguna de Aleusco, Chubut (-43.171 $\left.{ }^{\circ},-70.439^{\circ}\right)$ : CNP 3417, CNP 3418; (56) Las Plumas, Chubut

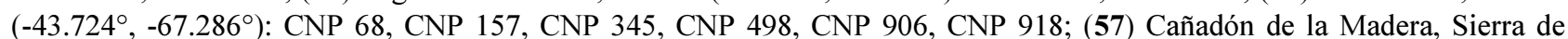
Tepuel, Chubut $\left(-43.852^{\circ},-70.728^{\circ}\right)$ : CNP 3320, CNP 3354; (58) Sierra de Tepuel, Chubut $\left(-43.852^{\circ},-70.728^{\circ}\right)$ : CNP 2385 , CNP 3319, CNP 3355; (59) Estancia Bajada del Guanaco, Chubut (-44.100 , -67.977 ): CNP 51, CNP 935, CNP 1023, CNP 1066, CNP 1081, CNP 1092, CNP 1100, CNP 1153, CNP 1176, CNP 1250, CNP 3348; (60) Camarones, Chubut (-44.801 ${ }^{\circ},-$ 65.712 ${ }^{\circ}$ ): CNP 1278, CNP 3241; (61) Pico Salamanca, Chubut (-45.409,$\left.-67.417^{\circ}\right)$ : CNP 2173, CNP 2174, CNP 2175, CNP 2176, CNP 2177, CNP 2178, CNP 2179, CNP 2180, CNP 2181, CNP 2182, CNP 2183, CNP 2186, CNP 2187, CNP 2260; (62) Hotel Los Manantiales, Chubut (-45.433 $\left.3^{\circ},-69.633^{\circ}\right)$ : CNP 4411, CNP 4481, CNP 4500; (63) Estancia los Manantiales, Chubut $\left(-45.508^{\circ},-67.489^{\circ}\right)$ : CNP 76; (64) margen SW Lago Musters, Chubut (-45.526 $\left.{ }^{\circ},-69.265^{\circ}\right)$ : CNP 3978; (65) Estancia 
Quichaura, Chubut (-45.707,$\left.-70.349^{\circ}\right)$ : CNP 1178; (66) W-SW Lago Blanco, Chubut (-45.922,$\left.-71.317^{\circ}\right)$ : CNP 318, CNP 338, CNP 392, CNP 418, CNP 1343; (67) 1 km E Lago Blanco, Chubut (-45.926º, -71.249): CNP 397, CNP 1263, CNP 1281; (68) Chile Chico, Aysen (-46.546,$\left.-71.724^{\circ}\right)$ : UACH 1824, UACH 1825; (69) Puesto sin techo, Meseta del Lago Buenos

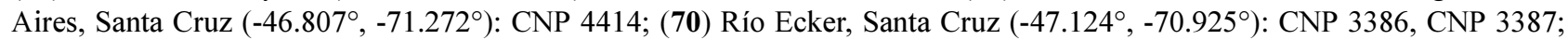
(71) Río Chico, Cajón del río Oro, $3 \mathrm{~km}$ O por camino del Puente del río Oro, Santa Cruz $\left(-47.442^{\circ},-71.933^{\circ}\right)$ : CNP 3825 , CNP 3829, CNP 3838, CNP 3842, CNP 3971, CNP 3975, CNP 4403, CNP 4482; (72) Río Chico, La Península, 2 km SSO camino de Tío Camping, Estancia La Península, Santa Cruz (-47.442 $\left.{ }^{\circ},-71.933^{\circ}\right)$ : CNP 3824, CNP 3832, CNP 3839, CNP 3926, CNP 3931, CNP 3932, CNP 3933, CNP 3968, CNP 3998, CNP 4453; (73) Río Chico, Valle del río Oro, 5 km O por camino del Puente del río Oro, Santa Cruz (-47.442 $\left.{ }^{\circ},-71.933^{\circ}\right)$ : CNP 3985, CNP 449; (74) $1 \mathrm{~km}$ E Estancia La Paloma, Santa Cruz (-47,661 $\left.,-67,738^{\circ}\right)$ : CNP 3315; (75) Estancia Cerro del Paso, Santa Cruz (-47.859 $\left.{ }^{\circ},-66.436^{\circ}\right)$ : CNP 3249, CNP 3253, CNP 3259, CNP 3262, CNP 3271, CNP 3272, CNP 3280, CNP 3281, CNP 3282, CNP 3285, CNP 3290, CNP 3291, CNP 3295, CNP 3321, CNP 3332, CNP 3333, CNP 3335, CNP 3339, CNP 3341, CNP 3385, CNP 3399, CNP 3404; (76) Estancia La Ensenada, Santa Cruz (-48,365 $\left.,-72,089^{\circ}\right)$ : CNP 3328, CNP 3378, CNP 3379, CNP 3388, CNP 3389, CNP 3390, CNP 3391, CNP 3393, CNP 3413; (77) Estancia Las Tunas, Lago Cardiel (-48,845, -71,360): CNP 3668, CNP 3670, CNP 3677, CNP 4086, CNP 4289, CNP 4301, CNP 4323, CNP 4325, CNP 4326; (78) Estancia Cerro Ventana, Santa Cruz (-48,966 ${ }^{\circ}$ 70,414 ): CNP 3243, CNP 3263, CNP 3274, CNP 3277, CNP 3278, CNP 3284, CNP 3306, CNP 3308, CNP 3324, CNP 3325, CNP 3326, CNP 3327, CNP 3334, CNP 3336, CNP 3337, CNP 3343, CNP 3381, CNP 3383, CNP 3398, CNP 3401, CNP 3409 . 